\title{
К ВОПРОСУ О ВЛИЯНИИ БИОГЕОХИМИЧЕСКИХ УСЛОВИЙ НА ЗАБОЛЕВАЕМОСТЬ COVID-19
}

\author{
М.B. Капитальчук \\ Приднестровский государственный университет, Молдова \\ e-mail: kapitalim@mail.ru
}

PЕЗЮМЕ. Обсуждаются возможные причины распространения COVID-19 в зависимости от экологических условий. Наименьшее количество зараженных отмечено в островных государствах и странах, расположенных на побережье. Возможно, это связано с влиянием океанического воздуха. Рассматривается возможное влияние на иммунитет населения Молдавии селенового статуса и загрязнения территории пестицидами. Имеются сведения о взаимосвязи селенового статуса населения с заболеваемостью COVID-19. Территорию Молдавии можно отнести к биогеохимическим провинциям с оптимальным содержанием селена в окружающей среде. Несмотря на то, что население Молдавии обеспеченно селеном, заболеваемость выше, чем в регионах с дефицитом селена. В этой стране в больших количествах использовались высокотоксичные и очень устойчивые хлорорганические пестициды, которые могли ослабить иммунитет населения Молдавии.

КЛЮЧЕВЫЕ СЛОВА: иммунитет, экологические условия, микроэлементы, COVID-19.

\section{ON THE IMPACT OF BIOGEOCHEMICAL CONDITIONS ON THE INCIDENCE OF COVID-19}

\section{M.V. Kapitalchuk}

Shevchenko State University of Pridnestrovie, Moldova e-mail: kapitalim@mail.ru

ABSTRACT. Possible causes of the spread of COVID-19 are discussed, depending on environmental conditions. The lowest number of infected people was observed in island states and located on the coast. Perhaps this is due to the influence of ocean air. The possible influence of the selenium status and the contamination of the territory with pesticides on the immunity of the Moldovian population is considered. There is information about the relationship selenium status of the population with the incidence of COVID-19. The territory of Moldova can be classified as a biogeochemical province with an optimal content of selenium in the environment. Despite the fact that the population of Moldova is provided with selenium, the incidence is higher than in regions with selenium deficiency. But, in this country, highly toxic and very resistant organochlorine pesticides were used in large quantities, which could weaken the immunity of the Moldovian population.

KEYWORDS: immunity, environmental conditions, trace elements, COVID-19.

\section{ВВЕДЕНИЕ}

Пандемия COVID-19 охватила весь мир. Однако количество зафиксированных случаев зараженных коронавирусом в разных странах существенно отличается. Из статистических данных на 28 февраля 2021 г. (представленные в Википедии) следует, что число зараженных на 1 млн варьирует от 6 до 140000. Иммунитет населения зависит от обеспеченности организма жизненно необходимыми элементами. На здоровье популяции также влияют социальные и экономические факторы.

Цель работы - изучение влияния биогеохимических условий проживания населения на заболеваемость COVID-19.

\section{РЕЗУЛЬТАТЫ И ОБСУЖДЕНИЕ}

При рассмотрении заболеваемости COVID-19 в странах мира можно выделить некоторые группы стран. Так, наименьшее количество зараженных отмечено в островных государствах (число зараженных на 1 млн): Вануату (3), Микронезия (9), Самоа (15), Соломоны острова (26), Маршаловы острова (67), Макао (73), Фиджи (66), Тайвань (40), а также в государствах, расположенных на побережье: Лаос (6), Западная Сахара (16), Танзания (8), Вьетнам (25). 
Государства с числом зараженных от 100 до 1000 на 1 млн: Папуа-Новая Гвинея (141), Новая Каледония (202), Либерия (392), Бруней (422), Сомали (448), Сьерра-Леоне (481), Новая Зенландия (475), Маврикий (479), Ангола (620), Мадагаскар (704), Эритрея (796) либо островные, либо большей частью расположены на побережье. Возможно, здесь сказывается влияние океанического воздуха. Однако невысокая заболеваемость встречается и во внутриконтинентальных странах: Бурунди (182), Нигер (191), Чад (237), Конго (284), Мали (406), Бенин (441), Буркина-Фасо (563), Судан (636), Южный Судан (703), Того (815), Уганда (865), Сирия (874). Эти страны расположены в Африке и Азии. В Западном полушарии можно отметить с невысокой заболеваемостью Гренландию (528) и Никарагуа (965), которые омываются океанами.

Государства с наибольшим количеством зараженных коронавирусом располагаются преимущественно в Европе (число зараженных на 1 млн): Андора (140 264), Черногория (120 732), Гибралтар (125 846), Чехия (115 277), Сан-Марино (109 365), Словения (91 423), Люксембург (87 622) и др. Высокая заболеваемость также характерна для Американского континента. Такой подход к анализу, видимо, не применим к крупным государствам, в которых наблюдаются разнообразные природные условия (Россия, США, Китай и др.).

Существуют сведения о том, что есть связь между обеспеченностью населения селеном и цинком с заболеваемостью COVID-19. Системные 15-летние исследования позволяют отнести территорию Молдавии к биогеохимическим провинциям с оптимальным содержанием селена в окружающей среде. В то же время пилотные данные указывают на недостаток цинка у населения. Число зараженных коронавирусом в Молдавии на 1 млн больше (46 044), чем в соседних - Украине (30 943) и России (29 088), но ближе к этому показателю Румынии (41 874). На здоровье популяции и иммунитет населения также сильно влияют другие факторы, например, наличие в окружающей среде стойких органических загрязнителей (СО3), таких как пестициды. Молдавия - государство с развитым сельским хозяйством, и в советское время пестициды тонами завозились на эту территорию. После запрета использования ДДТ в 1978 г. в Молдавии оставались более 600 тонн этого опасного загрязнителя. Все СО3 очень устойчивы в окружающей среде и вызывают ряд заболеваний, в первую очередь ослабление иммунитета населения. Массовое использование хлорорганических пестицидов в Молдавии, очевидно, существенно повлияло на здоровье популяции.

\section{ВЫВОДЫ}

Несмотря на то, что население Молдавии обеспечено жизненно необходимым элементом селеном, заболеваемость выше, чем в регионах с дефицитом селена. Для нормального функционирования живых организмов важно соотношение жизненно важных элементов и отсутствие опасных загрязнителей. Важным остается выявление соотношения биогенных элементов в организме человека, повышающее здоровье популяции и сопротивляемость организма инфекционным заболеваниям. 